\title{
Religiosity, self-control, and antisocial behavior: Religiosity as a promotive and protective factor
}

\author{
Robert D. Laird \\ University of New Orleans \\ Loren D. Marks \\ Brigham Young University - Provo, loren_marks@byu.edu \\ Matthew D. Marrero \\ University of New Orleans
}

Follow this and additional works at: https://scholarsarchive.byu.edu/facpub

Part of the Other Social and Behavioral Sciences Commons

\section{Original Publication Citation}

Laird, R., Marks, L. D., \& *Marrero, M. (2011). Religiosity, self-control, and antisocial behavior: Religiosity as a promotive and protective factor. Journal of Applied Developmental Psychology, $32,78-85$.

\section{BYU ScholarsArchive Citation}

Laird, Robert D.; Marks, Loren D.; and Marrero, Matthew D., "Religiosity, self-control, and antisocial behavior: Religiosity as a promotive and protective factor" (2011). Faculty Publications. 4878.

https://scholarsarchive.byu.edu/facpub/4878

This Peer-Reviewed Article is brought to you for free and open access by BYU ScholarsArchive. It has been accepted for inclusion in Faculty Publications by an authorized administrator of BYU ScholarsArchive. For more information, please contact ellen_amatangelo@byu.edu. 


\title{
Religiosity, self-control, and antisocial behavior: Religiosity as a promotive and protective factor
}

\author{
Robert D. Laird ${ }^{\mathrm{a}, *}$, Loren D. Marks ${ }^{\mathrm{b}}$, Matthew D. Marrero ${ }^{\mathrm{a}}$ \\ a University of New Orleans, New Orleans, LA, USA \\ ${ }^{\mathrm{b}}$ Louisiana State University, Baton Rouge, LA, USA
}

\section{A R T I C L E I N F O}

Article history:

Received 26 March 2010

Received in revised form 19 November 2010

Accepted 20 December 2010

Available online 26 January 2011

\section{Keywords:}

Religiosity

Self-control

Antisocial behavior

Adolescence

\begin{abstract}
A B S T R A C T
Three hypotheses with the potential to provide information on the role of religiosity as a promotive and protective factor in early adolescence were tested. Adolescents ( $N=166, M$ age $=13$ years, $49 \%$ female, $49 \%$ European American, 45\% African American) and mothers reported their own personal importance of religion and the frequency of their attendance of religious services. Greater mother importance and attendance was associated with greater adolescent importance and attendance. Mother importance was indirectly linked to adolescent antisocial behavior through adolescent importance. Less adolescent importance and attendance were associated with low self-control and low self-control was associated with more antisocial and rulebreaking behavior. Adolescent importance also moderated the links between low self-control and antisocial and rule-breaking behavior such that low levels of self-control were more strongly associated with more antisocial and rule-breaking behavior among adolescents reporting low religious importance compared to adolescents reporting high religious importance.
\end{abstract}

(c) 2010 Elsevier Inc. All rights reserved.

\section{Introduction}

In both adolescence and adulthood, greater religiosity is associated with more positive health-relevant outcomes (e.g., McCullough, Hoyt, Larson, Koenig, \& Thoresen, 2000; Powell, Shahabi, \& Thoresen, 2003). In adolescence, greater religiosity has been consistently linked with lower levels of involvement in a wide range of undesirable behaviors including alcohol, tobacco, and drug use, delinquency, and risky sexual behavior (e.g., Manlove, Logan, Moore, \& Ikramullah, 2008; Sinha, Cnaan \& Gelles, 2007; Wallace \& Williams, 1997; Wills, Gibbons, Gerrard, Murry, \& Brody, 2003). However, limited progress has been made toward understanding the processes linking religiosity with less problem behavior or toward understanding whether religiosity also functions as a protective factor. The current study tests three hypotheses to better understand whether and how religiosity functions as a promotive and protective factor in early adolescence.

\section{Religiosity as a promotive factor}

To date much of the theorizing about religion and health has been based on the direct association between religiosity and healthrelevant outcomes, emphasizing, for example, that high levels of religiosity are linked to better well-being (e.g., Smith, McCullough, \&

\footnotetext{
* Corresponding author. Department of Psychology, University of New Orleans, New Orleans, LA 70148, USA.

E-mail address: rlaird@uno.edu (R.D. Laird).
}

Poll, 2003) and that highly religious individuals live longer than less religious individuals (e.g., McCullough, Hoyt, Larson, Koenig, \& Thoresen, 2000). These effects are consistent with religion functioning as a general promotive factor associated with desirable outcomes. The search for processes underlying religion as a promotive factor focuses on identifying mediators of the association between religiosity and outcomes.

Geyer and Baumeister (2005) and McCullough and Willoughby (2009) identified self-control as a psychological process that may explain the link between religion and behavioral outcomes. In psychological research, self-control refers to a person's capacity to override and inhibit socially unacceptable and undesirable impulses and to regulate one's behaviors, thoughts and emotions (Baumeister, Heatherton, \& Tice, 1994; Carver, \& Scheier, 1998; Tangney, Baumeister, \& Boone, 2004). In their General Theory of Crime, Gottfredson and Hirschi (1990) conceptualize low self-control more broadly as a constellation of six characteristics: risk-seeking, preference for physical activities, non-verbal communication, shortsightedness, volatile temper and impulsivity (Grasmick, Tittle, Bursik, \& Arneklev, 1993). In this framework, individuals with low self-control are expected to engage in more antisocial behavior than individuals with high self-control because they tend to consider immediate benefits for themselves while failing to consider the long term consequences of their actions and how their actions may affect others (Gottfredson \& Hirschi, 1990). Numerous studies have shown that low self-control is a risk factor for a wide range of behaviors including criminal acts (Pratt \& Cullen, 2000), illicit and licit substance use (e.g., Vazsonyi, Pickering, Junger, \& Hessing, 2001; Wood, Pfefferbaum, \& 
Arneklev, 1993), risky sexual behavior (Jones \& Quisenberry, 2004), and risky driving (Hartos, Eitel, Haynie, \& Simons-Morton, 2000; Jones \& Quisenberry, 2004).

In contrast to Gottfredson and Hirschi's (1990) proposal that low self-control is determined by parenting in early childhood and remains stable thereafter, current conceptualizations view self-control as more dynamic and influenced by one's own exercise of self-control (Baumeister, Bratlafsky, Muraven, \& Tice, 1998) and social environmental factors (Hirschi, 2004). As such, self-control may be enhanced by participation in religious activities or adherence to religious beliefs (Geyer \& Baumeister, 2005). Following an extensive review of research on youth and adults linking religion with numerous correlates and dimensions of self-control, McCullough and Willoughby (2009) propose that religion affects health, well-being, and social behavior through selfcontrol. They note that although evidence that religion exerts a causal influence on self-control is lacking, the proposition is highly plausible given that both religiosity and self-control are consistent predictors of well-being. Evidence directly testing the mediation proposition in adolescence is limited to three studies of the association between religiosity and substance use. Two of the previous studies documented that associations between adolescent religiosity and substance use were mediated by self-control (Desmond et al., 2009; Walker, Ainette, Wills, \& Mendoza, 2007), whereas one study concluded that the link between the importance of religion and substance use was direct and not mediated by self-control (Wills, Gibbons, et al., 2003; Wills, Yaeger, \& Sandy, 2003). The first hypothesis in the current study focuses on selfcontrol as an explanation for the association between religiosity and antisocial behavior. We hypothesize that less adolescent religiosity will be associated with low self-control and with more antisocial behavior, and that the association between religiosity and antisocial behavior will be mediated by low self-control.

\section{Religiosity as a protective factor}

Although substantial evidence has accumulated that religiosity can function as a general promotive factor, religion is also expected to serve as a resource or source of support in times of need. In this manner, religiosity may function as an ameliorative or protective factor (Marks, 2008). The search for evidence of religiosity as a protective factor focuses on religiosity as a moderator of associations between risk factors and outcomes. Functioning as a protective factor, high levels of religiosity may be sufficient to buffer individuals from the negative impact of experiences or characteristics that put them at risk for maladaptive behavior or psychological problems. Smith and Denton (2005) note that for American adolescents (particularly "religiously devoted teens"), religion seems to provide "extra or more effective coping mechanisms for negotiating and resolving their mental, emotional, and interpersonal stresses and problems" (p. 245). Consistent with this perspective, high religiosity was found to protect adolescents from increasing substance use following negative life events (Wills, Yaeger, \& Sandy, 2003).

In terms of functioning as a protective factor for antisocial behavior, religion may provide adolescents with the motivation, psychological resources, coping, or social support necessary to avoid the temptation to engage in antisocial behavior or to fight one's predisposition to engage in antisocial behavior. More specifically, religiosity may moderate the effect of low self-control such that low self-control is less strongly linked with antisocial behavior among highly religious adolescents as compared to less religious adolescents. Only one study has tested religiosity as a moderator of low self-control in adolescence. Using the Add Health dataset, Desmond et al. (2009) failed to find significant interactions between adolescent religiosity and self-control when predicting marijuana and alcohol use. However, a study of college students found that high moral beliefs (i.e., how wrong it is to engage in antisocial behavior) moderated the association between low selfcontrol and antisocial behavior such that low self-control was unrelated to antisocial behavior at high levels of moral beliefs but was related to more antisocial behavior at low levels of moral beliefs (Schoepfer \& Piquero, 2006).The second hypothesis in the current study focuses on religiosity as a protective factor for low self-control. We hypothesize that religiosity will interact with self-control in the prediction of antisocial behavior such that low self-control will be less strongly associated with antisocial behavior among highly religious adolescents than among less religious adolescents.

\section{Parents' or adolescents' religiosity}

Many adolescents are actively involved in organized religious groups, regularly attend and participate in religious services, and report that their religious practices and beliefs are important (Smith \& Denton, 2005). Recent qualitative research even documents that some religious adolescents make significant sacrifices for their faith (Dollahite, Layton, Bahr, Walker, \& Thatcher, 2009). Good and Willoughby (2008) propose that adolescence is a sensitive period for the development of religiosity as the constellation of intrapersonal, cognitive, and neurological developments during adolescence may make adolescents particularly likely to explore religious ideas, experience a religious commitment, and make commitments that endure over time. However, such commitments are likely to be influenced by the opportunities afforded adolescents by their parents' religiosity.

Most adolescents are affiliated with the same religious organizations as their parents, attend services with their parents, and may have little choice in these matters (Yust, Johnson, Sasso, \& Roehlkepartain, 2006). Therefore, what are often reported as effects of adolescent religiosity may be effects of family or parent religiosity (Regnerus, 2003). Although studies rarely assess parents' and adolescents' religiosity using similar items, several studies indicate that effects of parent religiosity are mediated by adolescent religiosity (Burkett, 1993; Desmond, Ulmer, \& Bader, 2009; Simons, Simons, \& Conger, 2004; cf. Brody, Stoneman, \& Flor, 1996), suggesting that adolescent religiosity is the more proximal promotive and protective factor. The third hypothesis in the current study focuses on the distinction between religiosity as experienced personally by adolescents versus religiosity as a family or parent-level variable. We hypothesize that adolescents' and parents' personal religious experiences will be positively correlated, but that adolescents' personal religious experiences will mediate the link between adolescents' involvement in antisocial behavior and parents' own personal religious experiences.

A recent review indicates that the vast majority of social research on religion over the past 20 years has employed only one or two indicators of "religion" (Mahoney, 2010). In many cases, the only indicator used has been self-reported church attendance (Marks \& Dollahite, in press). This is problematic due to the tendency of Americans to over-report church attendance (Hadaway, Marler, \& Chavez, 1993). As a result, selfreported importance of religion has been used instead (or in addition) by some researchers (Miller \& Thoresen, 2003; Smith \& Denton, 2005). The present study assessed both attendance and importance. Differentiating between importance and attendance is essential because early adolescents are largely dependent on their parent(s) for transportation and many early adolescents attend religious services not because they are highly religious but because their parents require it. In other words, some early adolescents who want to attend religious services face resource constraints in doing so, whereas some others who attend services are not there voluntarily. We suspect that importance may be a better, or more consistent, promotive and protective factor than attendance.

In summary, the purpose of the current study is to test associations among religiosity, self-control, and antisocial behavior in early adolescence. We expect adolescent self-control to mediate the association between adolescent religiosity and adolescent antisocial behavior. Furthermore, we anticipate a significant interaction between adolescent religiosity and self-control when predicting antisocial 
behavior. Low self-control is anticipated to be less strongly linked with high levels of antisocial behavior among highly religious adolescents compared to less religious adolescents. In addition, we expect that parent and adolescent religiosity will be positively associated with one another, but expect that adolescent religiosity will mediate the association between parent religiosity and adolescent antisocial behavior. Finally, we will test the three hypotheses using two separate indicators of religiosity to determine whether the importance of religion and religious service attendance are similarly linked to self-control and antisocial behavior. All analyses will control for adolescent sex, parents' marital status, ethnicity, and family socioeconomic status as these variables may be responsible for spurious associations between religiosity and outcomes. Furthermore, analyses will control for antisocial behavior at an earlier time point such that religiosity and self-control will be used to predict rank-order change in antisocial behavior over a 1-year period in early adolescence.

\section{Method}

\section{Participants}

Data were provided by 166 early adolescents and their mothers. Most participants were 12-13 years old at the time of the interview ( $M$ age $=13.0$ years, $S D=1.1$, range $=11.73-15.76$ ). The sample was $49 \%$ female and $75.5 \%$ of the adolescents lived in a two-parent home when the data were collected. In terms of racial or ethnic background, 49\% of the sample was European American, non-Hispanic, 45\% was African American, and 6\% was Asian or Hispanic. Mother education level varied with $3 \%$ not having completed high school, $10.2 \%$ having a high school diploma, 33\% having attended college or technical school, 33\% having a bachelor's degree, and $20 \%$ having a graduate degree. The demographic characteristics of the sample generally correspond to those of the community and schools from which they were recruited. Specifically, Census 2000 data indicates that $68 \%$ of the households in the community with children $6-17$ years old were headed by married couples, and enrolment figures from the National Center for Educational Statistics indicate that the great majority of students in the schools are of White (47.2\%) or African American (49.6\%) background. Most (77\%) of the mothers reported being affiliated with a church or religious organization. In response to an open-ended request for their religious affiliation, mothers most often reported being affiliated with a Baptist (28\%), non-denominational Christian (23\%), or Catholic (17\%) Church. No other affiliation was reported by more than $5 \%$ of the respondents but a broad range of affiliations were reported.

\section{Procedure}

Following school administrator approval, participating families were recruited from 20 public elementary schools serving citizens of Baton Rouge, LA (population about 400,000). Participating families were recruited from two consecutive cohorts of 5th grade students (in 2006 and 2007). Research staff visited the schools to distribute invitations to participate in the study. Interested parents returned a postcard to the researchers or a form to the adolescents' school indicating their willingness to participate and were contacted to schedule a home interview. Postcards or forms were returned by $20 \%$ of the 5 th grade students enrolled in the schools and interviews were completed with $94 \%$ of the families contacted via telephone. This participation rate is comparable to the $27-33 \%$ reported by Smetana, Metzger, Gettman, and Campione-Barr (2006) for adolescents recruited in schools who took home questionnaire packets, completed them, and returned them to the school. Early adolescent and their mothers were interviewed in their homes in the summers following 5 th, 6 th, and 7 th grades. Each summer, consent and assent was discussed with the mother and adolescent together before the mothers and adolescents were interviewed in separate private locations within the home. To further ensure privacy and reduce social desirability bias, participants privately recorded their responses to the questions on an answer sheet so that verbal responses could not be overheard by other family members. The structured interviews took about $45 \mathrm{~min}$ and focused primarily on parentadolescent interactions and relationships. Religiosity, self-control, and antisocial behavior outcome data reported in the current study were collected during interviews in the summer of 2008 (i.e., the post-6th grade interview with the younger cohort and the post-7th grade interview with the older cohort) because this was the first time that the items on religiosity and self-control were included in the interview protocols. Antisocial behavior data from interviews 1 year earlier (i.e., 2007; post 5th and 6th grades for the younger and older, cohorts, respectively) were included in analyses as indices of previous behavior problems.

\section{Measures}

\section{Religiosity}

Mothers and adolescents each responded to two questions about their religious experiences. The first question assessed the importance of religion ("How important is religion to you in your daily life?") and was scored using a four-point scale (not very important, very important). The second question assessed the frequency of attendance at religious services ("How often do you attend religious services?") and was scored using a five-point scale (never, a few times a month, once a week, a few times a week, everyday). Separate importance and attendance scores were retained for mothers and adolescents.

\section{Self-control}

Adolescents reported on their own self-control using the Low SelfControl Scale (LSCS; Grasmick et al., 1993). The LSCS was developed to assess the 6 dimensions of self-control emphasized by Gottfredson and Hirschi (1990). Extensive psychometric work has been conducted on the LSCS and the scale has been shown to function reliably and validly in a diverse set of adolescent-age samples (Vazsonyi \& Belliston, 2007). The LSCS contains 24 items that comprise 6 subscales: impulsiveness, simple tasks, risk seeking, physical activity, self-centeredness, and temper. Items were scored on a five-point scale ranging from strongly disagree, strongly agree. Low self-control scores were computed as the mean of the 24 items $(\alpha=.88)$.

\section{Antisocial behavior}

Adolescents reported the frequency of their involvement in antisocial behavior during the last month of the school year using the Problem Behavior Frequency Scale (Farrell, Kung, White, \& Valois, 2000). The 26 items assess physical and non-physical aggression, delinquency, and drug use. Adolescents used a five-point scale (never, 7 or more times) to report how many times they engaged in each behavior during the last month of the previous school year. Adolescents reported on their antisocial behavior each year. A current antisocial behavior score was computed as the mean of the 26 items completed during the same interview as the religiosity and self-control items ( $\alpha=.90$ ). A previous antisocial behavior score was computed as the mean of the 26 items completed 1 year earlier $(\alpha=.92)$.

Mothers reported the frequency of their adolescents' rule-breaking behavior using the Teen Conflict Survey (Bosworth \& Espelage, 1995). The six items measure the frequency of rule-breaking behavior at home, school, and other contexts during the last month of the previous school year. Items are scored on a five point scale (never, 7 or more times). Current and previous rule-breaking behavior scores were computed as the means of the respective six items ( $\alpha$ s $=.81$ and .78 ).

\section{Results}

The mean response on the importance of religion items fell between the important, and very important response options with 
$8 \%$ of mothers and $10 \%$ of adolescents reporting that religion is not very important compared to $64 \%$ of mothers and $40 \%$ of adolescents reporting that religion is very important. The mean response on the frequency of attendance item fell between the a few times per month and once a week options with $16 \%$ of mothers and $15 \%$ of adolescent reporting that they never attend religious services compared with $24 \%$ of mothers and $28 \%$ of adolescents reporting that they attend services a few times a week or every day.

As shown in Table 1, mothers' and adolescents' reports of their own personal importance of religion and religious attendance were strongly, and positively, associated with one another. Likewise, mothers' importance and attendance were strongly associated with adolescents' importance and attendance, as expected. Furthermore, less adolescent religious importance was associated with lower selfcontrol and with more current adolescent-reported antisocial behavior. In contrast, adolescent attendance, mother importance, and mother attendance were not associated with low self-control, antisocial behavior or rule-breaking behavior. Girls and mothers of girls reported more religious importance than boys and mothers of boys. African American adolescents reported more attendance than European American adolescents, and mothers of African American adolescents reported more importance and attendance than mothers of European American Adolescents. Single mothers also reported more importance and attendance than married mothers.

\section{Path models}

To test the three primary hypotheses, two path models were fit in MPlus 5.2. Full information maximum likelihood estimation was used to deal with the small amount of missing data ( 12 cases were missing values for previous behavior problems; Schafer \& Graham, 2002). The two indices of religiosity - importance and attendance - were tested in separate models that were otherwise identical. The path model included five primary variables as shown in Fig. 1. The primary variables were mother religiosity, adolescent religiosity, low selfcontrol, adolescent-reported antisocial behavior and mother-reported rule-breaking behavior. The model included direct paths from mother religiosity to adolescent religiosity, adolescent-reported antisocial behavior, and mother-reported rule-breaking behavior. Likewise, the model included direct paths from adolescent religiosity to low selfcontrol, antisocial behavior, and rule-breaking behavior. Additional paths in the model were from low self-control to antisocial behavior and rule-breaking behavior. The Adolescent Religiosity $\times$ Low SelfControl interaction was a multiplicative term computed from centered variables as recommended by Cohen, Cohen, West, and Aiken (2003). The interaction term is represented in the figure by paths from adolescent religiosity to the paths from low self-control to antisocial and rule-breaking behavior. The covariance between the antisocial behavior and rule-breaking residuals also was estimated. Additional covariances (not shown) were estimated among the adolescent religiosity, self-control, and the interaction term residuals to ensure that the model was not misspecified. The model also included six covariates (i.e., previous antisocial behavior, previous rule-breaking behavior, gender, marital status, ethnicity, and mother education level) that are not shown in Fig. 1. The model included paths from all six covariates to each of the five primary variables and the interaction term (see Table 2 for path estimates). Mediation was tested via indirect effects using boot-strapped standard errors and bias-corrected confidence intervals as recommended by McCartney, Burchinal, and Bub (2006) because indirect effects are not normally distributed. Simple slopes calculated according to procedures described by Cohen et al. (2003) aided the interpretation of the interaction term used to test moderation.

\section{Importance of religion}

For religious importance, the path model provided a very good fit to the data, $\chi^{2}(2)=.50, p=.78, \mathrm{CFI}=1.00$, root mean square error of approximation (RMSEA) $=0.00$. Path estimates for the model including mother and adolescent perspectives on the importance of religion are provided in Fig. 1 before the slash. More mother religious importance predicted more adolescent religious importance but not less antisocial or rule-breaking behavior. More adolescent religious importance predicted less low self-control and less antisocial behavior. Adolescent religious importance did not predict rulebreaking behavior. Low self-control predicted more antisocial and rule-breaking behavior.

To determine whether low self-control mediates the association between adolescent religiosity and misbehavior, the indirect effects from adolescent religious importance to antisocial and rule-breaking behavior through self-control were estimated as a test of hypothesis 1 . The indirect effect was non-significant for both antisocial behavior, $b^{*}=-.043,95 \% \mathrm{CI}[-.09, .008]$, and rule-breaking behavior, $b^{*}=-.016$, $95 \% \mathrm{CI}[-.04, .01]$. Thus, results are not consistent with hypothesis 1 .

To determine whether religious importance moderates the association between self-control and misbehavior, the importance $\times$ selfcontrol interaction was included as predictor of misbehavior as a test of hypothesis 2. As shown in Fig. 2, and consistent with hypothesis 2, simple slopes indicated that low self-control was less strongly associated with antisocial behavior at high $(+1 S D)$ levels of adolescent religious importance, $b=.12, S E=.05, p=.026$, than at low $(-1 S D)$ levels of religious importance, $b=.36, S E=.05, p<.001$. Likewise, as shown in Fig. 3, simple slopes indicated that low self-control was less strongly associated with rule-breaking behavior at high levels of adolescent religious importance, $b=.02, S E=.08, p=.85$, than at low levels of religious importance, $b=.24, S E=.08, p=.004$.

Table 1

Bivariate correlations among religiosity, self-control, behavior problems, and control variables.

\begin{tabular}{|c|c|c|c|c|c|c|c|c|c|c|c|c|}
\hline Variable & 1. & 2. & 3. & 4. & 5. & 6. & 7. & 8. & 9. & 10. & 11. & 12. \\
\hline \multicolumn{13}{|l|}{ 1. Adol. Religious Importance } \\
\hline 2. Adol. Religious Attendance & $.51^{* * *}$ & & & & & & & & & & & \\
\hline 3. Mother Religious Importance & $.44^{* * *}$ & $.42^{* * *}$ & & & & & & & & & & \\
\hline 4. Mother Religious Attendance & $.33^{* * *}$ & $.58^{* * *}$ & $.60^{* * *}$ & & & & & & & & & \\
\hline 5. Low Self-Control & $-.20^{*}$ & -.14 & -.11 & -.05 & & & & & & & & \\
\hline 6. Previous Antisocial Behavior & -.12 & .02 & -.01 & .10 & $.39^{* * *}$ & & & & & & & \\
\hline 7. Current Antisocial Behavior & $-.22^{* *}$ & -.04 & -.03 & .07 & $.57^{* * *}$ & $.69^{* * *}$ & & & & & & \\
\hline 8. Previous Rule-Breaking & -.05 & .01 & -.05 & -.01 & .15 & $.31^{* * *}$ & $.28^{* * *}$ & & & & & \\
\hline 9. Current Rule-Breaking & -.03 & -.07 & -.07 & .01 & $.22^{* *}$ & $.23^{* *}$ & $.30^{* * *}$ & $.75^{* * *}$ & & & & \\
\hline 10. Male Sex & $-.24^{* *}$ & -.14 & $-.25^{* * *}$ & -.12 & $.23^{* *}$ & .14 & $.20^{*}$ & $.17^{*}$ & $.16^{*}$ & & & \\
\hline 11. Single Parent Home & .06 & .13 & $.15^{*}$ & $.21^{* *}$ & .10 & .15 & .14 & .07 & .05 & -.06 & & \\
\hline 12. Mother Education & -.01 & .08 & .01 & -.01 & $-.16^{*}$ & -.13 & $-.22^{* *}$ & -.04 & -.06 & -.03 & $-.18^{* *}$ & \\
\hline 13. African American Ethnicity & .14 & $.28^{* * *}$ & $.26^{* * *}$ & $.31^{* * *}$ & .07 & $.19^{*}$ & $.20^{*}$ & .07 & .04 & .02 & $.37^{* * *}$ & $-.19^{* *}$ \\
\hline
\end{tabular}

Note. $n \mathrm{~s}=153-166$.

${ }^{*} p<.05 .{ }^{* *} p<.01 .{ }^{* * *} p<.001$, two-tailed 


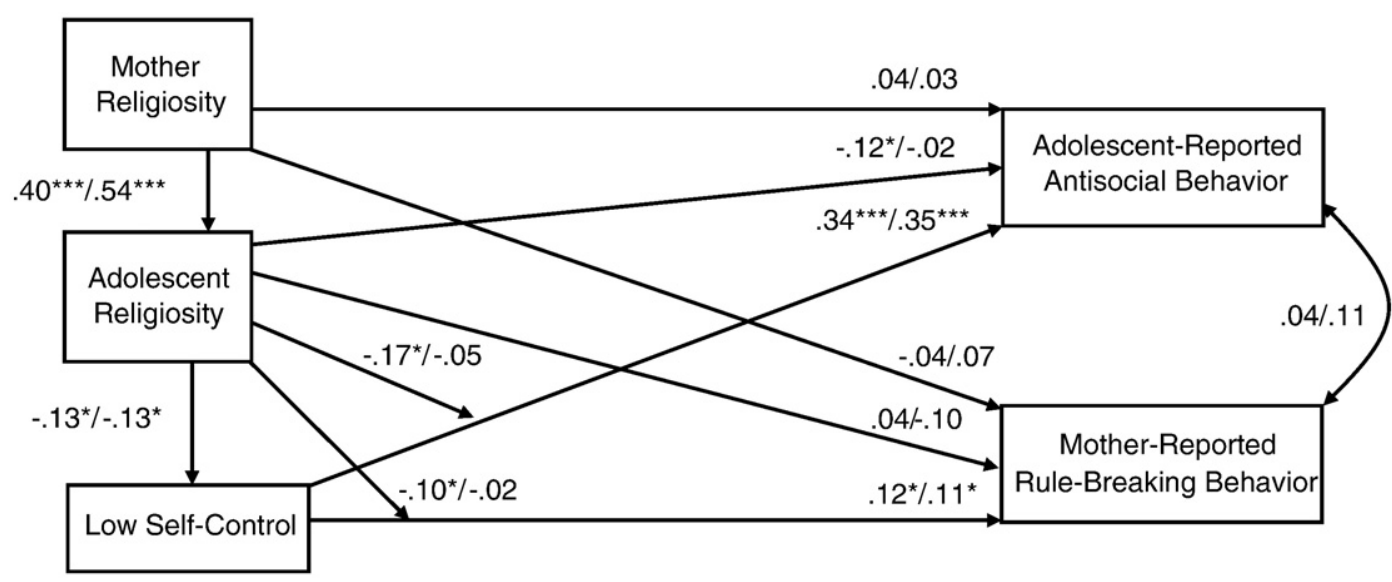

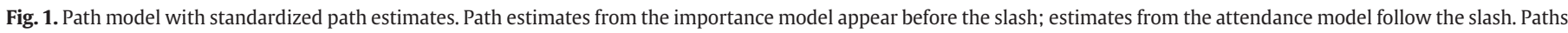
from six covariates to each variable shown are excluded for clarity (see Table 2 for the path estimates). ${ }^{* *} p<.05 .{ }^{* *} p<.01 .{ }^{* * *} p<.001$.

To determine whether adolescent religiosity mediates the association between mother religiosity and misbehavior, the indirect effects from mother religious importance to antisocial behavior and rulebreaking behavior through adolescent religious importance were estimated as a test of hypothesis 3. The total indirect effect from mother religious importance through adolescent religious importance to antisocial behavior (directly and through low self-control) was significant, $b^{*}=-.065,95 \% \mathrm{CI}[-.12,-.01]$, as was the specific indirect effect (not passing through self-control), $b^{*}=-.048,95 \% \mathrm{CI}[-.10$ to $-.001]$. Both the total indirect effect, $b^{*}=-.009,95 \%$ CI [-.05, .07], and the specific indirect effect, $b^{*}=-.006,95 \% \mathrm{CI}[-.02, .006]$, were non- significant predictors of rule-breaking behavior. Thus, results for antisocial behavior, but not for rule-breaking behavior, are consistent with hypothesis 3.

\section{Religious attendance}

For religious attendance, the path model provided a very good fit to the data, $\chi^{2}(2)=.10, p=.95$, CFI $=1.00$, RMSEA $=0.00$. Path estimates for the model including mother and adolescent attendance of religious services are provided in Fig. 1 following the slash. More mother religious attendance predicted more adolescent religious attendance but not less antisocial or rule-breaking behavior. More

Table 2

Standardized Path Estimates from Covariates to Primary Variables in the Importance and Attendance Path Models.

\begin{tabular}{|c|c|c|c|}
\hline Covariate & Primary Variable & Importance Model & Attendance Model \\
\hline Previous Antisocial Behavior & Adolescent Religiosity & -.12 & -.05 \\
\hline Previous Rule-breaking & Adolescent Religiosity & .02 & .02 \\
\hline Male Gender & Adolescent Religiosity & $-.13^{*}$ & -.06 \\
\hline Single Parent Home & Adolescent Religiosity & -.03 & -.02 \\
\hline Mother Education & Adolescent Religiosity & -.02 & .11 \\
\hline African American Ethnicity & Adolescent Religiosity & .07 & $.15^{*}$ \\
\hline Previous Antisocial Behavior & Mother Religiosity & -.02 & .07 \\
\hline Previous Rule-breaking & Mother Religiosity & -.02 & -.03 \\
\hline Male Gender & Mother Religiosity & $-.23^{* * *}$ & -.12 \\
\hline Single Parent Home & Mother Religiosity & .06 & .11 \\
\hline Mother Education & Mother Religiosity & .06 & .07 \\
\hline African American Ethnicity & Mother Religiosity & $.25^{* *}$ & $.27^{* * *}$ \\
\hline Previous Antisocial Behavior & Low Self-control (LSC) & $.32^{* * *}$ & $.33^{* * *}$ \\
\hline Previous Rule-breaking & Low Self-control & .03 & .03 \\
\hline Male Gender & Low Self-control & $.15^{*}$ & $.17^{*}$ \\
\hline Single Parent Home & Low Self-control & .06 & .06 \\
\hline Mother Education & Low Self-control & -.11 & -.09 \\
\hline African American Ethnicity & Low Self-control & -.02 & -.13 \\
\hline Previous Antisocial Behavior & Religiosity $\times$ LSC & .09 & $.20^{*}$ \\
\hline Previous Rule-breaking & Religiosity $\times$ LSC & -.04 & $-.17^{*}$ \\
\hline Male Gender & Religiosity $\times$ LSC & .05 & .06 \\
\hline Single Parent Home & Religiosity $\times$ LSC & .08 & .04 \\
\hline Mother Education & Religiosity $\times$ LSC & .07 & $.20^{*}$ \\
\hline African American Ethnicity & Religiosity $\times$ LSC & -.01 & -.02 \\
\hline Previous Antisocial Behavior & Antisocial Behavior & $.51^{* * *}$ & $.51^{* * *}$ \\
\hline Previous Rule-breaking & Antisocial Behavior & .04 & .04 \\
\hline Male Gender & Antisocial Behavior & .04 & .05 \\
\hline Single Parent Home & Antisocial Behavior & .01 & -.01 \\
\hline Mother Education & Antisocial Behavior & -.08 & -.08 \\
\hline African American Ethnicity & Antisocial Behavior & .07 & .06 \\
\hline Previous Antisocial Behavior & Rule-breaking & -.03 & -.04 \\
\hline Previous Rule-breaking & Rule-breaking & $.74^{* * *}$ & $.74^{* * *}$ \\
\hline Male Gender & Rule-breaking & .01 & .01 \\
\hline Single Parent Home & Rule-breaking & .02 & .00 \\
\hline Mother Education & Rule-breaking & -.02 & -.02 \\
\hline African American Ethnicity & Rule-breaking & -.03 & -.02 \\
\hline
\end{tabular}

${ }^{*} p<.05 .{ }^{* *} p<.01 .{ }^{* * *} p<.001$, two-tailed. 


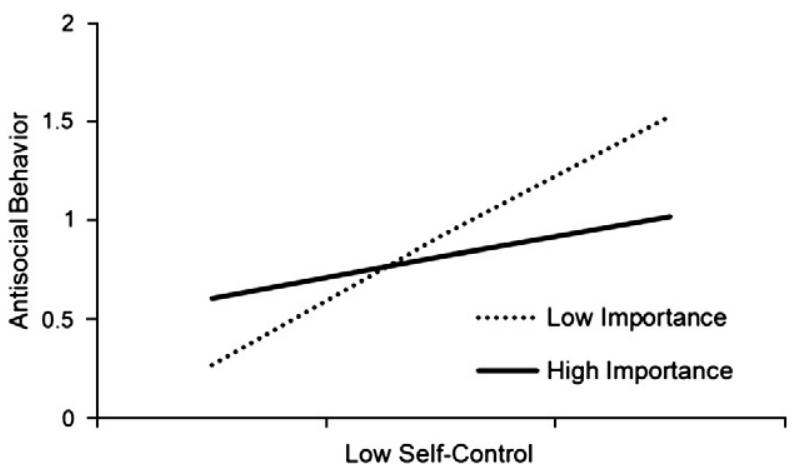

Fig. 2. Simple slopes showing the association between low self-control and antisocial behavior at high (+1SD) and low (-1 SD) levels of adolescent importance of religion.

adolescent religious attendance predicted less low self-control. Adolescent religious attendance did not predict antisocial or rulebreaking behavior. Low self-control predicted more antisocial and rule-breaking behavior.

Once again, the indirect effects from adolescent religious attendance to antisocial and rule-breaking behavior through self-control were estimated as a test of hypothesis 1 . The indirect effects from adolescent religious attendance through low self-control to both antisocial behavior, $b^{*}=-.047,95 \% \mathrm{CI}[-.10, .007]$, and rule-breaking behavior, $b^{*}=-.014,95 \% \mathrm{CI}[-.04, .01]$, were non-significant. Thus, results are not consistent with hypothesis 1 . Adolescent religious attendance did not moderate associations between self-control and antisocial behavior or rule-breaking behavior and thus results are not consistent with hypothesis 2 . Finally, the total indirect effect from mother religious attendance through adolescent religious attendance to antisocial behavior (directly and through low self-control), $b^{*}=-.035,95 \% \mathrm{CI}[-.12, .05]$ was non-significant as was the specific indirect effect (not passing through self-control), $b^{*}=-.01,95 \% \mathrm{Cl}$ [-.09 to .07]. Likewise, both the total indirect effect, $b^{*}=-.06,95 \% \mathrm{CI}$ $[-.15, .03]$, and the specific indirect effect, $b^{*}=-.008,95 \%$ CI $[-.02$, .008 ], were non-significant predictors of rule-breaking behavior. Thus, results for religious attendance are not consistent with hypothesis 3 .

\section{Discussion}

Three hypotheses with the potential to provide new information on the role of religiosity as a promotive or protective factor in early adolescence were tested. As anticipated, less adolescent religious importance and attendance were associated with lower levels of selfcontrol and low self-control was associated with more antisocial and rule-breaking behavior. However, tests of indirect effects were not significant indicating that self-control does not significantly mediate the association between adolescent religiosity and antisocial behavior. The non-significant indirect effect appears to be primarily a function of the relatively weak, but still statistically significant, link between religiosity and low self-control. McCullough and Willoughby (2009) provide a broad review of evidence of an association between religiosity and selfcontrol noting that across 14 cross-sectional studies of adults and children that standardized coefficients generally range from .2 to 4 . The effect size in the current study is .14 when controlling for earlier antisocial behavior and demographic characteristics. One possibility for variations in effect sizes across studies is that self-control can be conceptualized and operationalized in many different ways. The association between religiosity and self-control likely varies as a function of how self-control is assessed. In the current study, we measured low self-control because low self-control has been identified as a risk factor for antisocial behavior. However, good self-control and poor self-control are conceptualized as distinct constructs with different antecedents (Block \& Block, 1980; Rothbart \& Bates, 1998). Religiosity may be more effective at promoting good self-control than at elevating

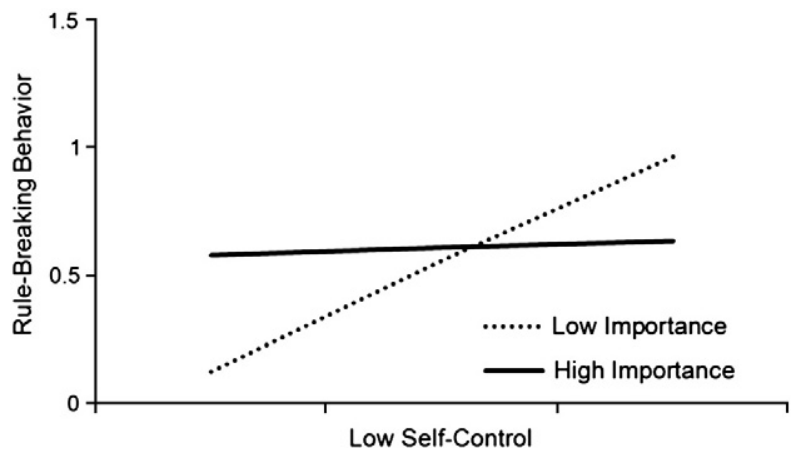

Fig. 3. Simple slopes showing the association between low self-control and rule-breaking behavior at high $(+1 S D)$ and low $(-1 S D)$ levels of adolescent importance of religion.

poor self-control (Walker et al., 2007), and therefore, good self-control may be a stronger mediator of the association between religiosity and antisocial behavior than low self-control.

Much of the theorizing and speculation about links between religiosity and positive health-related behaviors and outcomes has focused on the health promotion effect of religiosity. However, many scholars also have theorized and speculated about the protective effect of religiosity. High levels of religiosity may protect individuals who are otherwise at risk of, or inclined to engage in, misbehavior or healthcompromising behaviors (Roehlkepartain et al., 2006; Smith \& Denton, 2005). Moderation effects in the current study show that high levels of religious importance were able to protect low self-control individuals from involvement in antisocial behavior. Granted, low self-control puts individuals across the full range of religious importance at risk for antisocial and rule-breaking behavior, but the risk is significantly lower for highly religious adolescents. To the extent that religiosity moderates the effect of self-control, and potentially other predictors, main effects linking religiosity to outcomes underestimate the potential importance of religiosity. A modest protective effect allowed to accumulate over many years may account for the significant reduction in lifetime mortality found among individuals who regularly attend religious services-a longevity advantage of 7.6 years over non-attenders in one nationally representative sample, and a 13.7 year advantage among African Americans (Hummer, Rogers, Nam, \& Ellison, 1999; Marks, Nesteruk, Swanson, Garrison, \& Davis, 2005).

Adolescents who reported greater importance of religion in their daily lives and more frequent attendance at religious services had mothers who were likely to also report high levels of importance and frequent service attendance. Although mothers' personal religious experiences were not directly associated with adolescents' misbehavior, mothers' beliefs regarding the importance of religion were indirectly linked with adolescent antisocial behavior through adolescent importance. In other words, although there was not a main effect to mediate, greater mother importance was linked directly to greater adolescent importance, and indirectly through greater adolescent importance to antisocial behavior. Although parents may have a substantial role in directing and selecting early adolescents' opportunities to engage in organized religious activities, results converge with those from other studies (e.g., Burkett, 1993; Desmond et al., 2009; Simons et al., 2004) in showing that adolescents' beliefs regarding the importance and fidelity of such engagements appear to be more strongly and proximally linked to adolescents' misbehavior than are parents' religious beliefs and practices.

In addition to testing the three primary hypotheses, data from the current study address several other issues. First, although religious importance and attendance are strongly correlated, only importance was associated with antisocial behavior and only importance moderated the effect of low self-control on antisocial and rule-breaking behavior. These findings highlight the utility of differentiating between attendance and importance and converge with emerging evidence that religious importance may be a stronger promotive factor during adolescence 
than religious attendance (Gur, Miller, Warner, Wickramaratne, \& Weissman, 2005; Milot \& Ludden, 2009). Second, consistent with several previous studies, high levels of religiosity were more common among African American mothers and adolescents than among European American mothers and adolescents (Marks \& Chaney, 2007; Taylor, Chatters, \& Levin, 2004). Likewise, both girls and mothers of girls reported more importance of religion than boys or mothers of boys. Others have reported higher female religiosity (Koenig et al., 2001; Marks, 2005; Milot \& Ludden, 2009), but the finding that mothers of boys reported lower importance of religion than mothers of girls warrants further attention and replication.

Given the diversity of potential religious affiliations, experiences, and beliefs, no single study is likely to provide definitive answers to the questions generated by the religion-health connection. Nonetheless, the current study contributes to the literature by comparing mothers' and adolescents' religious experiences using a longitudinal multi-informant design that provided an opportunity to control for previous misbehavior (and contextual factors) and to test the generalizability of findings across mothers' and adolescents' reports of misbehavior. Although the main effect of importance was only significant for adolescent reports of misbehavior, low self-control was associated with both mother and adolescent reports of misbehavior, and religious importance moderated the effect of low self-control on both mother and adolescent reports of misbehavior. The sample includes both sexes and the demographic characteristics reflect the geographic area from which it was recruited but it remains a convenience sample from a single geographic location likely biased by both the low participation rate and the desire to collect data through personal interviews in the families' homes. Well-functioning families or well-behaved adolescents may be overrepresented in the sample. However, restricting the study geographically helped to control for regional variability in the importance of religion and religious and behavioral norms that may function as error variance or mask the effect of religiosity (Silk \& Walsh, 2006). The "Southern Crossroads Region" where the study was conducted is, based on selfreport survey data, among the most highly religious areas of the United States (Silk \& Walsh, 2006).

Results inform the debate over the source of the association between religiosity and health-relevant outcomes. Adolescents' personal experiences of religion are more strongly associated with their misbehavior than are mothers' religious experiences. Self-control may be an important psychological characteristic linking greater religiosity with the avoidance of undesirable behavior, but high levels of religiosity also buffer early adolescents with low self-control from engaging in antisocial behavior.

\section{Acknowledgements}

We thank the schools and families who participated in this research. This research was supported by grants from the National Science Foundation (BCS 0517980 and 0807650) to the first author.

\section{References}

Baumeister, R. F., Heatherton, T. F., \& Tice, D. M. (1994). Losing control: How and why people fail at self-regulation. San Diego: Academic Press.

Baumeister, R. F., Bratlafsky, E., Muraven, M., \& Tice, D. M. (1998). Ego depletion: Is the active self a limited resource? Journal of Personality and Social Psychology, 74, $1252-1265$

Block, J. H., \& Block, J. (1980). The role of ego-control and ego-resiliency in the organization of behavior. In W. A. Collins (Ed.), Minnesota symposium on child psychology, Vol. 13. (pp. 39-101)Hillsdale, NJ: Erlbaum.

Bosworth, K., \& Espelage, D. (1995). Teen conflict survey. Unpublished manuscript, Center for Adolescent Studies, Indiana University.

Brody, G. H., Stoneman, Z., \& Flor, D. (1996). Parental religiosity, family processes, and youth competence in rural, two-parent African American families. Developmental Psychology, 32, 696-706.

Burkett, S. R. (1993). Perceived parents religiosity, friends drinking, and hellfire: A panel study of adolescent drinking. Review of Religious Research, 35, 134-154.
Carver, C. S., \& Scheier, M. F. (1998). On the self-regulation of behavior. New York, NY: Cambridge University Press.

Cohen, J., Cohen, P., West, S. G., \& Aiken, L. S. (2003). Applied multiple regression/correlation analysis for the behavioral sciences (3rd ed.). Mahwah, NJ: Lawrence Erlbaum.

Desmond, S. A., Ulmer, J. T., \& Bader, C. D. (2009). Religion, self control, and delinquency. Manuscript submitted for publication.

Dollahite, D. C., Layton, E., Bahr, H. M., Walker, A. B., \& Thatcher, J. Y. (2009). Giving up something good for something better: Sacred sacrifices made by religious youth. Journal of Adolescent Research, 24, 691-725.

Farrell, A. D., Kung, E. M., White, K. S., \& Valois, R. F. (2000). The structure of selfreported aggression, drug use, and delinquent behaviors during early adolescence. Journal of Clinical Child Psychology, 29, 282-292.

Geyer, A. L., \& Baumeister, R. F. (2005). Religion, morality, and self-control: Values, virtues, and vices. In R. F. Paloutzian \& C. L. Park (Eds.), Handbook of the psychology of religion and spirituality (pp. 412-432). New York, NY: Guilford.

Good, M., \& Willoughby, T. (2008). Adolescence as a sensitive period for spiritual development. Child Development Perspectives, 2, 32-37.

Gottfredson, M. R., \& Hirschi, T. (1990). A general theory of crime. Stanford, CA: Stanford University Press.

Grasmick, H. G., Tittle, C. R., Bursik, R. J., \& Arneklev, B. J. (1993). Testing the core empirical implications of Gottfredson and Hirschi's general theory of crime. Journal of Research in Crime and Delinquency, 30, 5-29.

Gur, M., Miller, L., Warner, V., Wickramaratne, P., \& Weissman, M. (2005). Maternal depression and the intergenerational transmission of religion. Journal of Nervous and Mental Disease, 193, 338-345.

Hadaway, C. K., Marler, P. L., \& Chavez, M. (1993). What the polls don't show: A closer look at U.S. church attendance. American Sociological Review, 58, 741-752.

Hartos, J. L., Eitel, P., Haynie, D. L., \& Simons-Morton, B. G. (2000). Can I take the car? Relations among parenting practices and adolescent problem-driving practices. Journal of Adolescent Research, 3, 352-367.

Hirschi, T. (2004). Self-control and crime. In R. Baumeister \& K. Vohs (Eds.), Handbook of self-regulation: Research, theory, and applications (pp. 537-552). New York, NY: Guilford.

Hummer, R., Rogers, R., Nam, C., \& Ellison, C. G. (1999). Religious involvement and U.S adult mortality. Demography, 36, 273-285.

Jones, S., \& Quisenberry, N. (2004). The general theory of crime: How general is it? Deviant Behavior, 25, 401-426.

Koenig, H. G., McCullough, M. E., \& Larson, D. B. (2001). Handbook of religion and health New York, NY: Oxford University Press.

Mahoney, A. (2010). Religion in families 1999-2009: A relational spirituality perspective. Journal of Marriage and Family, 72, 805-827.

Manlove, J., Logan, C., Moore, K. A., \& Ikramullah, E. (2008). Pathways from family religiosity to adolescent sexual activity and contraceptive use. Perspectives on Sexual and Reproductive Health, 40, 105-117.

Marks, L. D. (2005). Religion and bio-psycho-social health: A review and conceptual model. Journal of Religion and Health, 44, 173-186.

Marks, L. D. (2008). Prayer and marital intervention: Asking for divine help...or professional trouble? Journal of Social and Clinical Psychology, 27, 678-685.

Marks, L. D., \& Chaney, C. (2007). Faith communities and African American families: A qualitative look at why the black church matters. In S. D. Ambrose (Ed.) Religion and psychology: New research (pp. 277-294). Hauppauge, NY: Nova Science.

Marks, L. D., \& Dollahite, D. C. (in press). Mining the meanings from psychology of religion's correlation mountain. Journal of Psychology of Religion and Spirituality.

Marks, L. D., Nesteruk, O., Swanson, M., Garrison, M. E. B., \& Davis, T. (2005). Religion and health among African Americans. Research on Aging, 27, 447-474.

McCartney, K., Burchinal, M. R., \& Bub, K. L. (2006). Best practices in quantitative methods for developmentalists. Monographs of the Society for Research in Child Development, 71(3, Serial No. 285).

McCullough, M. E., Hoyt, W. T., Larson, D. B., Koenig, H. G., \& Thoresen, C. E. (2000) Religious involvement and mortality: A meta-analytic review. Health Psychology, 19, 211-222.

McCullough, M. E., \& Willoughby, B. L. B. (2009). Religion, self-regulation, selfcontrol: Associations, explanations, and implications. Psychological Bulletin, 135, 69-93.

Miller, W. R., \& Thoresen, C. (2003). Spirituality, religion, and health: An emerging research field. American Psychologist, 58, 24-35.

Milot, A. S., \& Ludden, A. B. (2009). The effects of religion and gender on well-being, substance use, and academic engagement among rural adolescents. Youth E Society, 40, 403-425.

Powell, L. H., Shahabi, L., \& Thoresen, C. E. (2003). Religion and spirituality: Linkages to physical health. American Psychologist, 58, 36-52.

Pratt, T. C., \& Cullen, F. T. (2000). The empirical status of Gottredson and Hirschi's general theory of crime: A meta-analysis. Criminology, 38, 931-964.

Regnerus, M. D. (2003). Linked lives, faith, and behavior: Intergenerational religious influence on adolescent delinquency. Journal for the Scientific Study of Religion, 42, 189-203.

Roehlkepartain, E. C. King P. E. Wagener, L. \& Benson, P. L. (Eds.). (2006). The handbook of spiritual development in childhood and adolescence. Thousand Oaks, CA: Sage.

Rothbart, M. K., \& Bates, J. E. (1998). Temperment. In W. Damon (Series Ed.) \& N Eisenberg (Vol. Ed.), Handbook of child psychology: Vol. 3. Social, emotional, and personality development (5th ed., pp. 105-176). New York, NY: Wiley.

Schoepfer, A., \& Piquero, A. R. (2006). Self-control, moral beliefs, and criminal activity Deviant Behavior, 27, 51-71.

Schafer, J. L., \& Graham, J. W. (2002). Missing data: Our view of the state of the art Psychological Methods, 7, 147-177. 
Silk, M., \& Walsh, A. (2006). Religion by region: Religion and public life in the United States. Blue Ridge Summit, PA: AltaMira.

Simons, L. G., Simons, R. L., \& Conger, R. D. (2004). Identifying the mechanisms whereby family religiosity influences the probability of adolescent antisocial behavior. Journal of Comparative Family Studies, 35, 547-563.

Sinha, J. W., Cnaan, R. A., \& Gelles, R. J. (2007). Adolescent risk behaviors and religion: Findings from a national study. Journal of Adolescence, 30, 231-249.

Smetana, J. G., Metzger, A., Gettman, D. C., \& Campione-Barr, N. (2006). Disclosure and secrecy in adolescent-parent relationships. Child Development, 77, 201-217.

Smith, C., \& Denton, M. L. (2005). Soul searching: The religious and spiritual lives of American teenagers. New York: Oxford University Press.

Smith, T. B., McCullough, M. E., \& Poll, J. (2003). Religiousness and depression: Evidence for a main effect and the moderating effect of stressful life events. Psychological Bulletin, 129, 614-636.

Tangney, J. P., Baumeister, R. F., \& Boone, A. L. (2004). High self-control predicts good adjustment, less pathology, better grades, and interpersonal success. Journal of Personality, 72, 271-322.

Taylor, R., Chatters, L., \& Levin, J. (2004). Religion in the lives of African Americans. Thousand Oaks, CA: Sage.

Vazsonyi, A. T., Pickering, L. E., Junger, M., \& Hessing, D. (2001). An empirical test of a general theory of crime: A four-nation comparative study of self-control and the prediction of deviance. Journal of Research in Crime and Delinquency, 38, 91-131.
Vazsonyi, A. T., \& Belliston, L. M. (2007). The family $\rightarrow$ Low self-control $\rightarrow$ Deviance: A cross-cultural and cross-national test of self-control theory. Criminal Justice and Behavior, 34, 505-530.

Walker, C., Ainette, M. G., Wills, T. A., \& Mendoza, D. (2007). Religiosity and substance use: Test of an indirect-effect model in early and middle adolescence. Psychology of Addictive Behaviors, 21, 84-96.

Wallace, J. M., Jr., \& Williams, D. R. (1997). Religion and adolescent healthcompromising behavior. In J. Schulenberg, J. L. Maggs, \& K. Hurrelmann (Eds.), Health risks and developmental transitions during adolescence (pp. 444-468). New York, NY: Cambridge University Press.

Wills, T. A., Gibbons, F. X., Gerrard, M., Murry, V. M., \& Brody, G. H. (2003). Family communication and religiosity related to substance use and sexual behavior in early adolescence: A test for pathways through self-control and prototype perceptions. Psychology of Addictive Behaviors, 17, 312-323.

Wills, T. A. Yaeger, A. M. \& Sandy, J. M. (2003). Buffering effect of religiosity for adolescent substance use. Psychology of Addictive Behaviors, 17, 24-31.

Wood, P. B., Pfefferbaum, B., \& Arneklev, B. (1993). Risk-taking and self-control: Social psychological correlates of delinquency. Journal of Research in Crime and Delinquency, 16, 111-130.

Yust, K., Johnson, A. N., Sasso, S. E., \& Roehlkepartain, E. C. (Eds.). (2006). Nurturing childhood and adolescent spirituality: Perspectives from the world's religious traditions. Lanham, MD: Rowman \& Littlefield. 